\title{
DO PRICES AFFECT FARMER'S TERM OF TRADE IN INDONESIA?
}

\author{
Saad Murdy ${ }^{* 1}$ \\ *) Faculty of Agriculture, University of Jambi \\ Jl. Lintas Jambi, Muara Bulian, Muaro Jambi, Jambi 36122
}

\begin{abstract}
This study aimed to identify the factors affecting the welfare of food crop farmers, measured by the food crop farmers' terms of trade using the Vector Error Correction Model. The data used were monthly data from 2011 to 2016. The results of this study indicate that the medium-grain rice producer price and sharia financing provided by Sharia Banks in the agricultural sector contribute greatly to the welfare of the food crop farmers.
\end{abstract}

Keywords: farmers'terms of trade, food crops, sharia financing, food price

\begin{abstract}
Abstrak: Penelitian ini bertujuan mengidentifikasi faktor-faktor yang memengaruhi kesejahteraan petani tanaman pangan, yang diukur dengan nilai tukar petani tanaman pangan dengan menggunakan Vector Error Correction Mode. Data yang digunakan adalah data bulanan dari 2011-2016. Hasil penelitian ini menunjukkan bahwa harga produsen beras gabah medium dan pembiayaan syariah yang diberikan oleh Bank Syariah di sektor pertanian memberikan kontribusi yang besar terhadap kesejahteraan petani tanaman pangan.
\end{abstract}

Kata kunci: nilai tukar petani, tanaman pangan, pembiayaan syariah, harga pangan

\section{INTRODUCTION}

Indonesia still faces serious poverty problem. The rapid accumulation of wealth and the strengthening of position and status of some rich people have created income distribution inequality. In the period of 1990 to $2012,1 \%$ of the rich of the world's population have been able to increase their wealth by more than $60 \%$ (Oxfam, 2012). Unfair distribution has been identified as the major cause of poverty of millions of people worldwide (Ismail et al. 2013).

In 2015, the number of poor people remained high, namely, around 28.51 million, and about $62.74 \%$ of them lived in rural areas (BPS, 2017). The rural poor are mostly still working in the agricultural sector, and in 2015, the poor people in Indonesia increased by 17.94 million from 17.73 million in 2014 (Arifin, 2016). The high rate of rural poverty is due to the fact that development policies tend to be biased in favor of urban and industrial sectors, while the budget allocation for agricultural sector has dropped dramatically (Sajogyo, 2002).

\footnotetext{
${ }^{1}$ Corresponding author:

Email: Ssad_murdy@yahoo.com
}

The decrease of budget allocation for the agricultural sector is very unfortunate because the agricultural sector has a strategic role in the national economic development. There are more than $60 \%$ of the Indonesian population living from the agricultural sector, staying in rural areas and who are part of the low-income group. This group of people should be the central point of national development, especially in the direction of investment (Nurul, 2016).

Farmers' terms of trade (FTT) that describe that the welfare of Indonesian farmers had merely been around 100-105 from 2010 to the end of 2013 and experienced a decrease in 2014 which was around 99-102 (BPS, 2016). These values are certainly lower than the lower limit target of the National Medium Term Development Plan (RPJMN) in 2010-2014, which was 115-120 (BPKP, 2009). These values indicate that Indonesian farmers are not prosperous yet. The reason of FTT low values can be seen from the price index received by the farmers (It) and the price index paid by the farmers (Ib). In terms of It, the diversification of food consumption is still difficult to do. This is caused by the culture of the Indonesian people who consume rice or certain basic foods, and this is difficult to change. Therefore, the dependence on food consumption is still high. In terms of $\mathrm{Ib}$, the delay in agricultural input assistance such as seeds and fertilizers often occurs. Usually, 
budget cannot be easily liquefied at the beginning of the year, whereas farmers should start planting at this time (DPR, 2016). The movement of farmers' terms of trade in the study period of 2011-2016 in Figure 1.

Based on the study conducted by Sriana (2011), the government should allocate its spending more on productive sectors, one of which is the agricultural sector. In Figure 2, it can be seen that the number of gross domestic product of food crops, horticulture, and plantations has an increasing trend. This shows that the contribution of the agricultural sector is increasing. In addition to having a large contribution to GDP, according to Jayadi (2012), the agricultural sector also has a strategic role in the national economy to improve the welfare of farmers, increase economic growth, and reduce poverty rate.

In addition to the inconsiderable amount of allocated budget, the farmers have difficulties in accessing bank credit. They have some constraints to meet the formal requirements required by banks. This is a dilemma because in the provision of credit, banks are constantly bound by the applicable regulations so they require certain conditions to be met by creditors. The government seeks credit development in the agricultural sector; on the other hand, banks, through the regulations of Bank Indonesia, emphasize the prudential principle in each of its financial distribution by imposing risk on any credit quality reduction without special treatment (Ashari and Saptana, 2005).

The absence of capital as an essential element in increasing the production and living standard of the community becomes a constraint in the flexibility of agricultural sector (Hamid in Assad, 2011). The characteristics of agricultural businesses that have many risks are the reason for the relatively low interest of financing institutions to fund this sector. Thus, to ensure the sense of justice for agricultural actors, it is necessary to open a discourse on an alternative financing model that corresponds to the business characteristics in the agricultural sector. One of the applied models is sharia scheme.

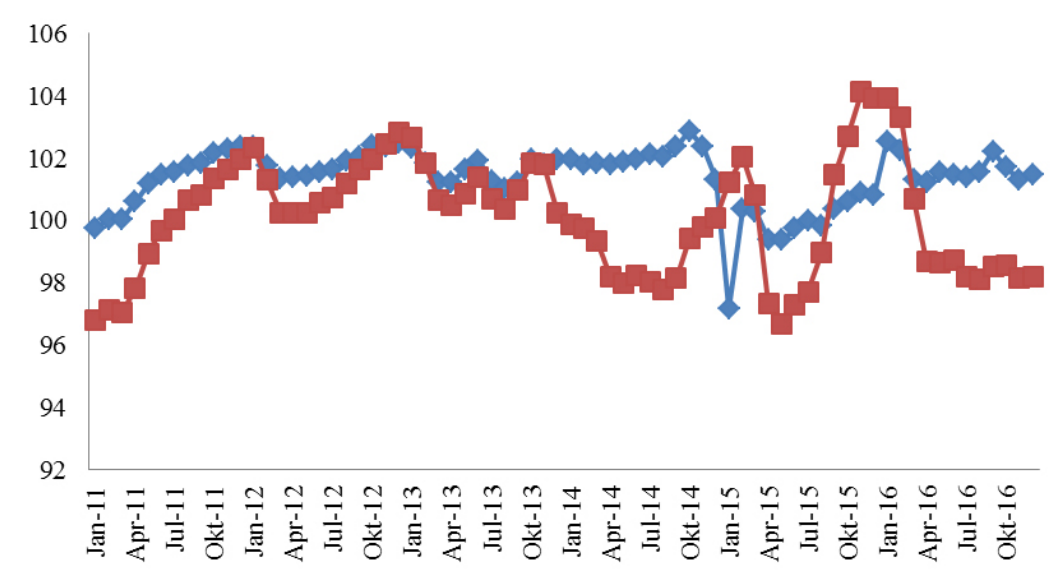

Figure 1. The movement of farmers' terms of trade in the study period of 2011-2016 (BPS, 2016)

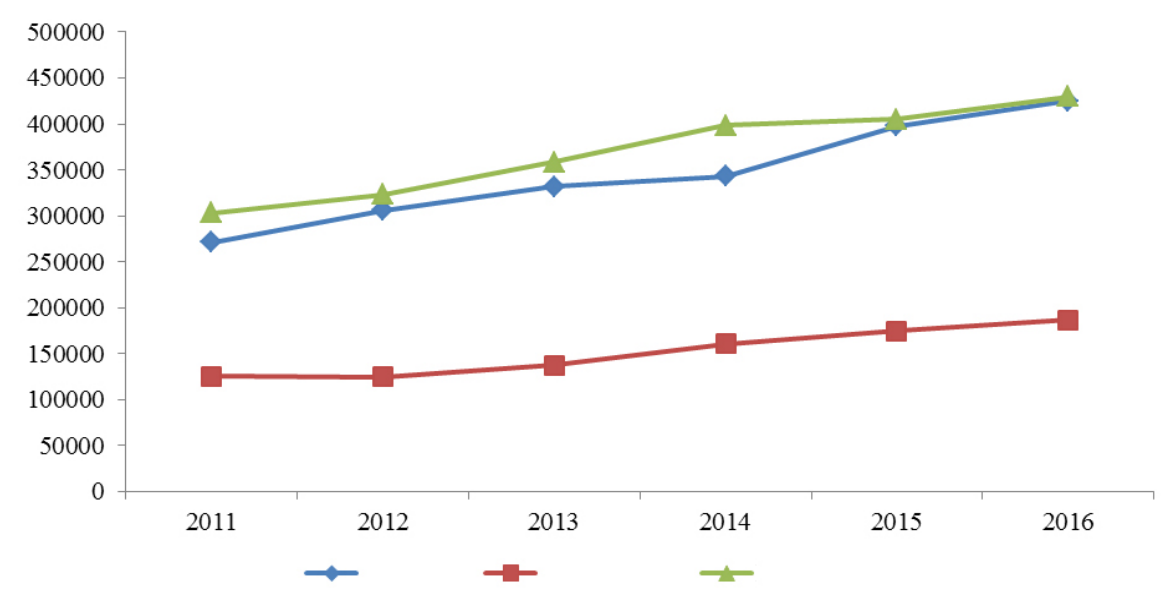

Figure 2. The number of gross domestic product (GDP) of food crops, horticulture, and plantations (BPS, 2017) 
The characteristics of sharia financing pattern are more suitable to farmers. This is because: (1) Sharia banks do not recognize interest calculation but use profit sharing principle and profit taking on sale and purchase, (2) The principle of profit sharing and the amount of profit share between fund owner or bank and business manager or farmer are determined by both parties and are adjusted to the harvest season, (3) The agreed ratio for smallincome farms is not the same as that of larger income businesses, considering that each agricultural commodity has different income rate as well as different harvest period, (4) Farmers are not burdened with loan interest, instead the payment is automatically adjusted to the harvest period (Assad, 2011). Based on the formulation above, then the scope for the purpose of this study was to identify the factors affecting the welfare of food crop farmers in Indonesia in terms of wages, capital, and agricultural product prices.

\section{METHODS}

The data used in this study were secondary time series data. The data used to identify the factors affecting the welfare of Indonesian farmers were taken from the monthly data period of 2011-2016. The secondary data were obtained from various sources, including the general publications of the Ministry of Finance (Kemenkeu), Statistics Indonesia (BPS), Bank Indonesia (BI), Financial Services Authority (OJK), the Ministry of Trade (Kemendag), books, published individual papers, and research journals. The data used in this study were data pooling from all provinces in Indonesia. The software programs used in this study were Microsoft Excel 2007 to classify the data and SPSS 11 as well as Eviews 8 to process the data. Types and sources of data are presented in Table 1.

The Method of Vector Error Correction Model (VECM)

Vector Error Correction Model (VECM) is a restricted form of VAR. This additional restriction has to be given because of the existence of the non-stationary form at a level; VECM then utilizes the cointegration restriction information into its specification (Firdaus, 2011). Therefore, VECM is often referred to as a VAR design for non-stationary series which has cointegration relationship. Thus, VECM contains the speed of adjustment from short-term to long-term (Firdaus, 2011). The model specifications of VECM used in this study are as follows:

$$
\Delta y_{t}=\mu_{x}+\mu_{1} x_{t}+\Pi_{x} y_{t-1}+\sum_{i=1}^{k-1} \Gamma_{x i} \Delta y_{t-1}+\varepsilon_{t}
$$

Where: $\Delta y_{t}$ (vector containing the variables analysed in the study); $\mu_{0 x}$ (intercept vector); $\mu_{1 x}$ (regression coefficient vector $) ; \Pi_{x}\left(\alpha \times \beta^{\prime}\right.$ where $\beta^{\prime}$ contains the longterm cointegration equation); $\mathrm{y}_{\mathrm{t}-1}$ (in-level variable); $\Gamma_{\mathrm{xi}}$ (regression coefficient matrix); k-1(the order of VECM from VAR); $\varepsilon_{t}$ (error term).

The variables used to identify the factors affecting the welfare of food crop farmers were food crop farmers' terms of trade (FFTT), real wages of landless farm workers, Sharia Commercial Bank (BUS) and Sharia Business Unit (UUS) financing in the agricultural sector, BPRS financing in the agricultural sector, local soybean price, and medium-grain rice price. Local soybean price and medium-grain rice price were selected because of the availability of more complete data compared to other food commodities. Hence, there were three models used in this study, namely:

$$
\begin{aligned}
\mathrm{Ntpp}_{\mathrm{t}}= & \alpha_{0}+\sum_{\mathrm{i}=1}^{7} \alpha_{1} \operatorname{Riil}_{\mathrm{t}-1}+\sum_{\mathrm{i}=1}^{7} \alpha_{2} \mathrm{Us}_{\mathrm{t}-1}+\sum_{\mathrm{i}=1}^{7} \alpha_{3} \mathrm{Bprs}_{\mathrm{t}-1}+ \\
& \sum_{\mathrm{i}=1}^{7} \alpha_{4} \mathrm{Klk}_{\mathrm{t}-1}+\sum_{\mathrm{i}=1}^{7} \alpha_{5} \mathrm{Klp}_{\mathrm{t}-1}+\sum_{\mathrm{i}=1}^{7} \alpha_{6} \mathrm{Bmk}_{\mathrm{t}-1^{+}} \\
& \sum_{\mathrm{i}=1}^{7} \alpha_{7} \mathrm{Bmp}_{\mathrm{t}-1}+\varepsilon_{\mathrm{it}}
\end{aligned}
$$

Discription: Ntpp $\mathrm{t}_{\mathrm{t}}$ (Food crop farmers' terms of trade of the tth period); Riil (Real wages of landless farm workers of the th period); $\mathrm{Us}_{\mathrm{t}}$ (Total financing provided by BUS and UUS in the agricultural sector of the th period); Bprs ${ }_{t}$ (Total financing provided by BPRS in the agricultural sector of the th period); $\mathrm{Klk}_{\mathrm{t}}$ (Local soybean consumer price per kilogram of the tth period); $\mathrm{Klp}_{\mathrm{t}}$ (Local soybean producer price per kilogram of the th period); $\mathrm{Bmk}_{\mathrm{t}}$ (Medium-grain rice consumer price per kilogram of the th period); $\mathrm{Bmp}_{\mathrm{t}}$ (Medium-grain rice producer price per kilogram of the th period); $\alpha_{\mathrm{ij}}$ (Regression coefficient model VECM); $\varepsilon_{i t}$ (Error term of variable $i$ at time $\left.t\right)$.

The steps taken in analyzing the data began with a preestimation test consisting of stationary test, optimal lag test, VAR stability test, and cointegration test. If the data were proven to be stationary at the first difference and had a cointegration equation, then the next step would be to estimate VECM to determine the effects of study variables on the welfare of food crop farmers which were measured by FFTT. To determine the responses of the welfare of food crop farmers on the shocks occurring on the observed research variables, Impulse Response Function (IRF) was conducted. The 
final step was the analysis of Forecast Error Variance Decomposition (FEVD) which was used to determine the contribution of observed research variable shocks in affecting the welfare of farmers.

\section{1) Data Stationarity Test}

The first step taken in applying the VAR model was to test the stationarity of variables by using unit root test. A set of data is stationary if the mean and variance of the time series data are not systematically changed over time. Meanwhile, the time series data mostly had average values and varied variances so the data became non-stationary. Data that are non-stationary or contain unit roots will generate spurious regression, which is a regression that describes the relationship between two variables that are statistically significant when in fact they are not.

\section{2) Optimal Lag Test}

The determination of the number of optimal lag was the second step that was necessary to do in using the VAR model. The optimal lag test on data utilized some information, namely the Likelihood Ratio (LR), Akaike Information Criterion (AIC), Schwarz Criterion (SC) and Hanan-Quinn (HQ).

\section{3) VAR Stability Test}

VAR stability test was performed by calculating the roots of a polynomial function or known as the roots of characteristic polynomial. If all the roots of the polynomial function are within the unit circle, then the VAR model will be considered stable, therefore the Impulse Response Function (IRF) and Forecast Error Variance Decomposition (FEVD) generated are deemed to be valid (Firdaus, 2011).

\section{4) Cointegration Test}

The cointegration test aims to determine whether the non-stationery variables are cointegrated or not. The cointegration concept was proposed by Engle-Granger in 1987 as a linear combination of two or more nonstationary variables. This linear combination is known as the cointegration equation and can be interpreted as a long-term equilibrium relationship between variables (Firdaus, 2012). The cointegration test can be done in three ways, namely, the Cointegrating Regression Durbin Waston (CDRW) test and the Johansen Cointegration test (Firdaus, 2011). If the variables in the equation are cointegrated, then the Vector Error Correction Model (VECM) analysis can be performed.

\section{5) Impulse Response Function (IRF)}

Impulse Response Function (IRF) is a method used to determine the response of an endogenous variable to a certain shock. This is due to the fact that the ith variable shock does not only affect the ith variable, but it is also transmitted to all other endogenous variables through the dynamic structure or the lag structure in VAR. IRF measures the impact of a shock at a time on the innovation of endogenous variables at the moment and in the future (Firdaus, 2011). IRF analysis in this study was conducted to see the responses of food crop farmers' terms of trade to the research variable shocks. The duration used in projecting this IRF was the next 30 periods.

Table 1. Types and sources of data

\begin{tabular}{lcc}
\hline \multicolumn{1}{c}{ Data used } & Unit & Source \\
\hline Food Crop Farmers' Terms of Trade & Index & BPS \\
Real Wages of Landless Farm Workers & Rupiah & BPS \\
BUS and UUS Financing & Billion Rupiah & BI and OJK \\
BPRS Financing & Billion Rupiah & BI and OJK \\
Local Soybean Consumer Price & Rupiah & Kemendag \\
Medium-grain Rice Consumer Price & Rupiah & Kemendag \\
Local Soybean Producer Price & Rupiah & BPS \\
Medium-grain Rice Producer Price & Rupiah & BPS \\
\hline
\end{tabular}


6) Forecast Error Variance Decomposition (FEVD)

Forecast Error Variance Decomposition (FEVD) aims to see a change in a variable, indicated by a change in the error variance which is influenced by other variables. FEVD characterizes a structure in the VAR/ VECM model. By calculating the age of the squared prediction error of the future kth stage of a variable due the innovation on other variables, the difference between error variances before and after the shock coming from oneself or from other variables can be seen. Therefore, through FEVD, the factors affecting the fluctuation of certain variables can be identifies. In this study, FEVD would discuss the contribution of the research variable shocks in explaining food crop farmers' terms of trade. Just like IRF analysis, the time periods used in projecting this FEVD were the next 30 periods.

\section{RESULTS}

\section{The Effects of the Research Variable Shocks on Farmers' Terms of Trade}

Impulse Response Function (IRF) was used to observe the movements and responses between the variables in the current period and forecasting variable conditions in case of shocks. In this study, IRF analysis was used to see the responses provided by the food crop farmers' terms of trade (FFTT) to the research variable shocks over the next 30 periods. In Figure 3, the real wage shock of one standard deviation was not responded by FFTT in the first month.

Farmers' crop exchange rate (FFTT) responded negatively to the real wage shock of landless farm workers. FFTT response started to achieve its stabilization in the 19th month at $0.013621 \%$. This result indicates that the real wage shock of landless farm workers will encourage the weakening of FFTT. The result of the study conducted by Febriana et al in 2015 has shown that the wage variable has significantly negative effect on farmers' terms of trade in East Java Province. If wages experience an increase, then farmers' terms of trade will experience a decrease. This proved that if the wages of landless farm workers increase, then they will affect the production cost paid by farmers. Higher production cost paid by famers will result in the decrease of farmers' terms of trade.
Figure 4 shows that the BUS and UUS financing shock in the agricultural sector have caused FFTT to respond negatively. The shock of sharia financing provided by BUS and UUS have received negative responses. This is due to the low equity-based financing, such as mudharabah and musharakah (profit sharing) in sharia commercial banks as well as sharia business units. Financing provided by BUS and UUS is still dominated by debt-based financing, such as murabahah (sale and purchase), which makes Islamic banking is similar in nature to conventional banking (Ascarya, 2010).

As Islamic banking is based on the Sharia law, its operations must comply with the applicable law, but sharia commercial banks as commercial banks which are an integral part of the banking system in Indonesia are subjected to the laws or regulations stipulated by the government and Bank Indonesia (Muhammad in Assad, 2011). Islamic banks in principle must be willing to bear the risk of high financing due to the reliance on the profit-sharing contracts, but sharia commercial banks and sharia business units are forced by strict prudential rules, so they use more contracts of sale and purchase that are similar to conventional credit (Fathurrahman in Assad, 2011).

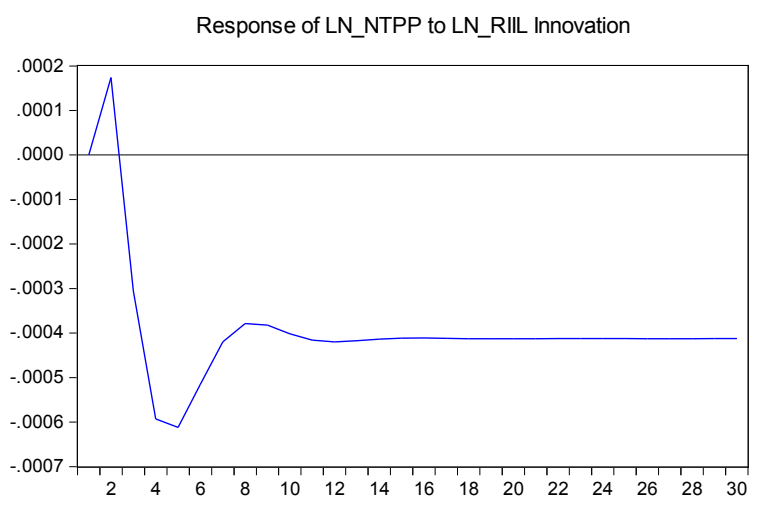

Figure 3. FFTT response to real shock

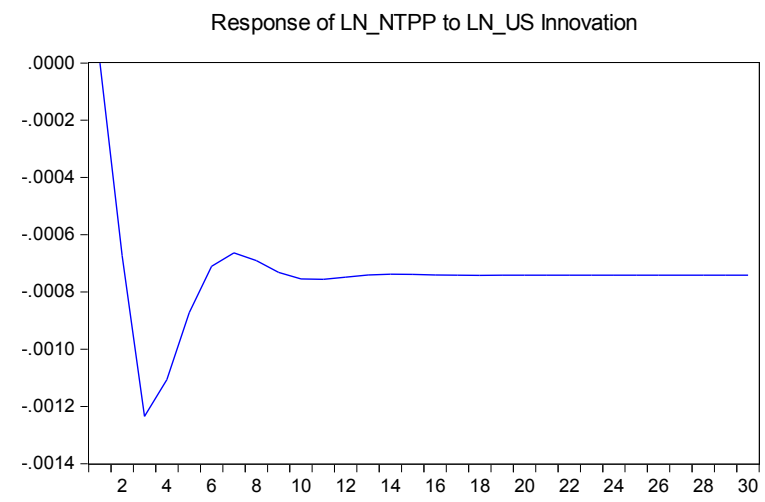

Figure 4. FFTT response on US shock 
FFTT response to BPRS financing variable shock in the agricultural sector can be seen in Figure 5. BPRS shock of one standard deviation in the first month was not responded by FFTT. BPRS financing shock in the agricultural sector received negative responses from FFTT. FFTT variable started to stabilize in the 20th month with a response of $0.002926 \%$.

BPRS financing in the agricultural sector received negative response from FFTT. BPRS offers financing; one of them is the financing of murabahah contracts, so that sharia financing provided by BPRS in the agricultural sector can increase farmers' capital. The application of murabahah contracts is generally followed by monthly payment instalments. However, the condition of most farmers does not allow them to have sufficient income to pay the principal at a monthly time range (Rodiana et al. 2014). This is because food crop and horticultural agriculture depend greatly on seasons; thus, the risks owned by food crop and horticultural farmers are very high. Therefore, an increase in murabahah financing in the long run will cause an increase in farmers' obligation to pay.

Figure 6 shows FFTT response on local soybean consumer price shock. Local soybean consumer price shock (Klk) has a received positive response from FFTT. In the first month, the shock of one standard deviation was not responded by FFTT. FFTT variable of local soybean consumer price shock received a positive response in the long run and achieved stability at $0.001098 \%$ in the 17 th month.

FFTT responses on local soybean producer price shocks can be seen in Figure 7. From the second to the thirtieth month, the local soybean producer price shocks (Klp) received positive responses. FFTT response on the local soybean producer price shocks achieved the stability in the $23 \mathrm{rd}$ month with a response of $0.002873 \%$.

The result indicates that the increase in local soybean consumer price can improve the welfare of farmers, both national level and food crop farmers. Therefore, if there is an increase in soybean consumer price, the government should not import soybeans so that the farmers can feel the benefits of rising prices. To strengthen the farmers in order to increase soybean production, it is necessary to consider the government's policy in giving indirect subsidy to farmers through the price of quality seeds and the use of agricultural machine tools (Adisarwanto, 2010).
In Figure 8, the shock that occurred in the medium rice consumer price caused FFTT to give a positive response in the long run. In the first month, the shock of one standard deviation was not responded by FFTT. From the second to the thirtieth month, the medium-grain rice consumer price shock in the agricultural sector received a positive response. FFTT response towards the medium-grain rice consumer price shock received a positive response in the long run and achieved stability in the 18th month with a positive response of $0.000947 \%$.

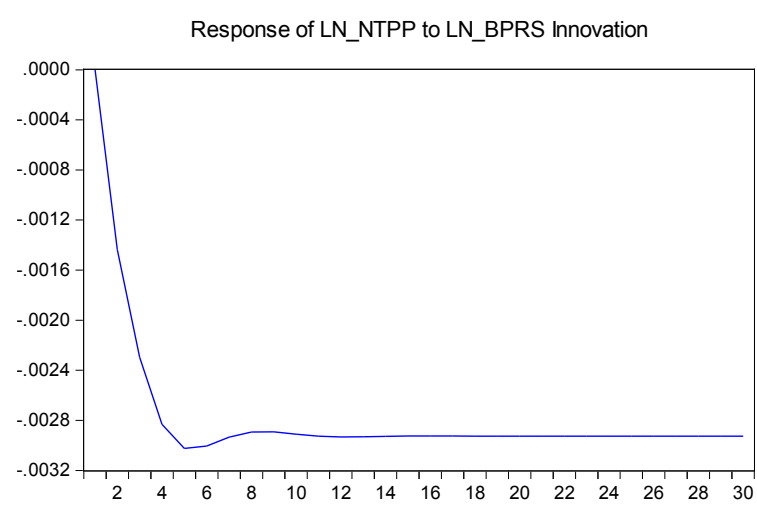

Figure 5. FFTT response to BPRS shock

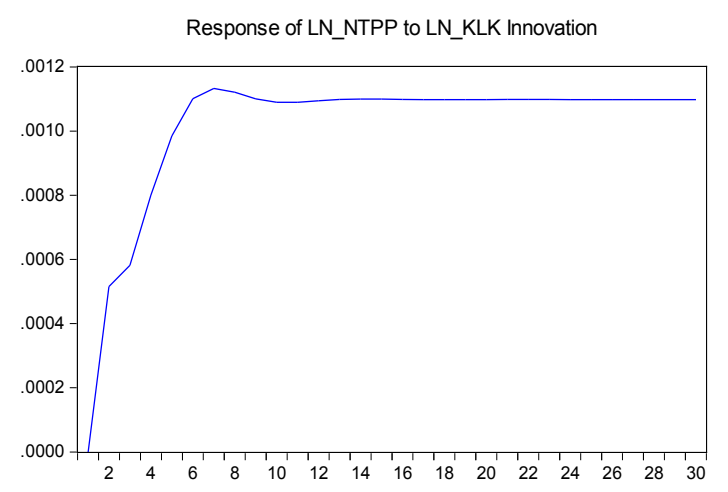

Figure 6. FFTT response on local soybean consumer price shock

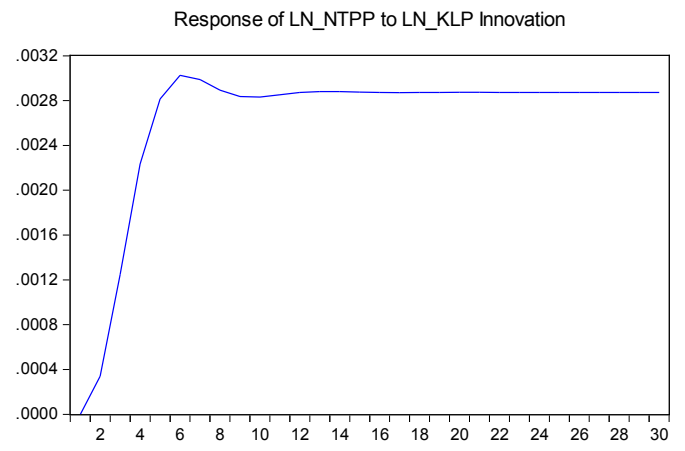

Figure 7. FFTT response on local soybean producer price shock 
The medium-grain rice producer price shock received a negative response from FFTT from the second to the thirtieth month. In the first month, the shock of one standard deviation was not responded by FFTT. FFTT response to the medium-grain rice producer price shock (Figure 9) also achieved stability in the 23rd month, but the response provided was negative at $0.004613 \%$.

The medium-grain rice consumer price shock will indicate slightly the quantity of medium-grain rice in the market; hence, the consumers' demand on mediumgrain rice will improve This is because medium-grain rice is the staple food of the Indonesian people, so even if there is an increase in price, the people still have to buy rice to meet their needs. Increased producer prices are caused by extreme weather factor and high production cost. As a result, high prices in the market do not necessarily reflect that the income and welfare of farmers are also high. The welfare of farmers becomes negative due to decreased production caused by bad weather which increases rice producer prices.

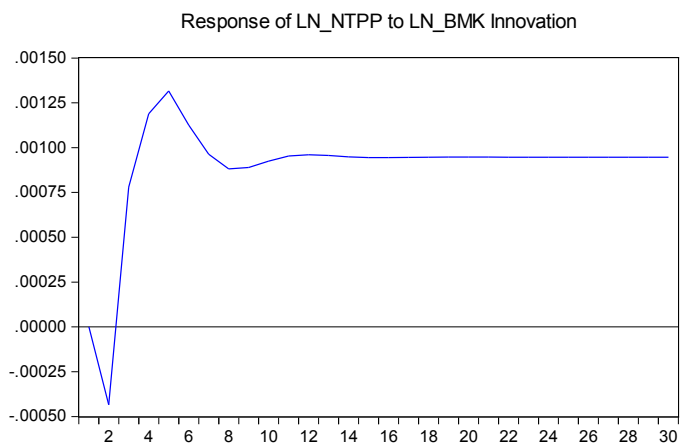

Figure 8 . FFTT response to the medium-grain rice consumer price shock

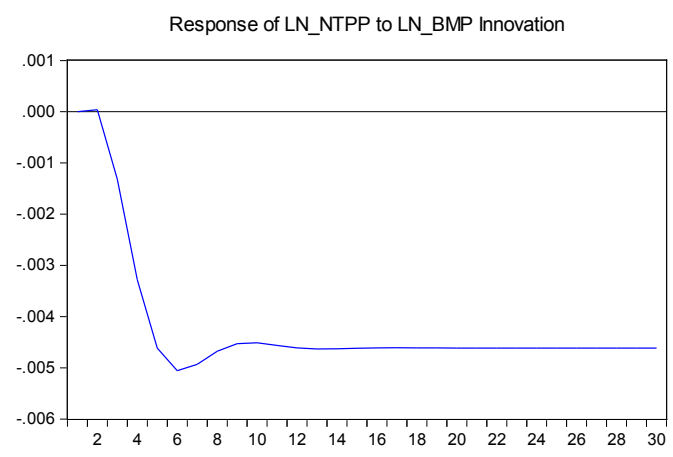

Figure 9. FFTT response to the medium-grain rice producer price shock

\section{The Contribution of Research Variables in Influencing Farmers' Terms of Trade}

Forecast Error Variance Decomposition (FEVD) aims to explain the contribution of each variable to the shock it causes to the main observed variables. This study aimed to describe the contribution percentage of each research variable shock so that the strengths and weaknesses of each variable in influencing food crop farmers' terms of trade can be seen. The time period used in explaining this FEVD was 30 periods.

In the first period, FFTT movement shock was only affected by the FFTT movement shock itself. In the second period, it appeared that other variables were beginning to affect FFTT. In the third to the thirtieth period, it appeared that other variables began to affect FFTT. In the period of 3 to 30, FFTT diversity was influenced greatly by itself, medium-grain rice producer price with the contribution of $8.83 \%$ and the financing of Sharia Rural Banks in the agricultural sector of $3.68 \%$. Medium-grain rice producer price became the variable that contributed the most in affecting the welfare of food crop farmers.

Meanwhile, BPRS financing in the agricultural sector became the most dominant variable of both effects. This is because there are about $50 \%$ of rice farmers in Java Island and almost $40 \%$ of rice farmers are outside Java Island. The food crop farmers meet their farming capital needs through loans with average individual loan of more or less Rp900,000 per hectare per planting season and Rp1,300,000 per hectare per planting season (Darwis and Iqbal, 2010).

The thing people usually think about to help farmers directly is to subsidize fertilizers and seeds. According Syafa'at et al. 2006, fertilizer has an important and strategicroleinordertoincreaseproduction, productivity, quality, and competitiveness of agricultural products of food crops, horticulture, smallholder, livestock and fisheries. Therefore, fertilizer is deemed to be necessary to be subsidized. According to Dermoredjo (2014), fertilizer subsidy policy will produce agricultural products with the quality standards desired by the actors of result processing, marketing (distributor), and consumers. So, if the government aims to improve the quality and quantity of agricultural commodities, then the government needs to increase fertilizer subsidy. 
However, the results of study conducted by Osorio et al. (2011) stated that approximately $40 \%$ of large farmers get more than $60 \%$ of the fertilizer subsidy. This indicates that the majority of subsidized fertilizers cannot be utilized by small farmers, while fertilizer subsidy procurement aims to assist small scale farmers. According to Bambang Cahyono, the Director of Marketing of Indonesian Fertilizer, the leak occurs in areas that set larger allocations than needed, areas that specify allocations exceeding government provisions, areas near plantations and in areas around fertilizer plants. In addition, the realization of seed subsidy budget of Rp1.6 trillion in 2014 did not reach 50\% (Firdaus, 2015).

According to the study conducted by Saptana et al. (2013), state-owned enterprises sold subsidized seeds outside the planting season. This is because the cooperation agreement on the implementation of sales and distribution of subsidized seeds was delayed, so there was a difficulty in the procurement of seeds at the level of state-owned enterprises, as a result of a delay in government assignment letter for procurement and distribution of subsidized seeds and state-owned enterprises' lack of courage to take risk.

In developed countries, it is common to avoid subsidies that are considered capable of distorting the market, such as applying government purchase prices and subsidizing agricultural input prices. The US government channels additional income to corn farmers in cash. In the category of agricultural subsidies, this is classified as output subsidy.

Farmers do not expect to get a decent price since when the harvest comes, it is already the most beautiful gift for them. The key is to strengthen the bargaining position of farmers against village collectors or mills. Implementing direct income subsidy to rice farmers is a right choice. With the high opportunity cost of growing rice, while the government should maintain the price of rice in order to stay "cheap", then it is reasonable if rice farmers earn a decent extra income.

In addition, the increase in Islamic finance in the equity-based agricultural sector, such as mudharabah and musharakah in sharia commercial banks, sharia business units as well as sharia financing banks also needs to be reached, if the debt-based sharia financing, such as murabahah, has a negative impact on the welfare of national farmers. Islamic banks in principle have to be willing to assume high financing risks due to the reliance on the profit-sharing contracts, but sharia commercial banks and sharia business units are forced by the strict prudential rules, so Bank Indonesia and the Financial Services Authority need to create policies or programs that support sharia commercial banks and sharia business units to improve profit share-based financing.

\section{Managerial implications}

To improve the welfare of farmers, easy access in accessing capital for farming finance is required; therefore, it is necessary to increase financing in the agricultural sector, with the principle of sharia bank or sharia business unit that must be willing to bear the risk of financing, as well as necessary policies or programs that support sharia commercial banks and sharia business units by Bank Indonesia and the Financial Services Authority.

\section{CONCLUSIONS AND RECOMMENDATIONS}

\section{Conclusions}

Based on the result of the study, it can be concluded that, the low food crop farmers' terms of trade indicate that the farmers are still not prosperous, and the factors influencing the food crop farmers' terms of trade are regular red chili consumer and producer prices, medium-grain rice producer prices and sharia financing provided by BPRS in the agricultural sector.

\section{Recommendations}

The Indonesian government needs to undertake a deeper review on the agricultural sector funding policy so that the funds issued are effective and right on target, such as subsidizing direct income to farmers. Controlling the price of agricultural products, especially mediumgrain rice producer prices, needs to be done because medium-grain rice producer prices greatly contribute to the welfare of farmers. Equity-based sharia financing in the agricultural sector needs to be improved. This is because credit-based sharia financing will respond negatively to FTT, HFTT, and FFTT. BI and OJK have to create policies or programs that support Islamic banking in order to improve equity-based financing. 


\section{REFERENCES}

Adisarwanto T. 2010. Strategi peningkatan produksi kedelai sebagai upaya untuk memenuhi kebutuhan di dalam negeri dan mengurangi impor. Pengembangan Inovasi Pertanian 3(4): 319-331.

Arifin B. 2016. Menatap ekonomi pangan dan pertanian 2016. http://news.metrotvnews.com. [8 Novemebr 2016]

Ascarya. 2010. Peranan perbankan syariah dalam transmisi kebijakan moneter ganda. Iqtisodia, Jurnal Ekonomi Islam Republika August 26, 2010: 5.

Ashari, Saptana. 2005. Prospek pembiayaan syariah untuk sektor pertanian. Forum penelitian agro ekonomi 23(2): 132-147. https:/doi. org/10.21082/fae.v23n2.2005.132-147.

Assad M. 2011. Peningkatan peranan perbankan syariah untuk pembiayaan usaha pertanian. MIQOT: Jurnal ilmu-ilmu keislaman 35(1):113-127.

[BPKP] Badan Pengawas Keuangan dan Pembangunan. 2009. Rencana pembangunan jangka menengah nasional 2010-2014. http://www.bpkp.go.id/. [23 Maret 2017]

[BPS] Badan Pusat Statistik. 2016. Indeks harga yang diterima petani (it), indeks harga yang dibayarkan petani (ib), dan nilai tukar petani (ntp) menurut provinsi, 2008-2015). http://www.bps.go.id/. [8 November 2016].

[BPS] Badan Pusat Statistik. 2017. Jumlah penduduk miskin, persentase penduduk miskin, dan garis kemiskinan, 1970-2015. http://www.bps.go.id/. [20 Februari 2017].

[BPS] BadanPusatStatistik. 2017. [Seri 2000] PDB triwulanan atas dasar harga konstan 2010 menurut lapangan usaha (miliar rupiah) 20102013. http://www.bps.go.id/. [25 Juli 2017].

[BPS] BadanPusatStatistik. 2017. [Seri 2000] PDB triwulanan atas dasar harga konstan 2010 menurut lapangan usaha (miliar rupiah) 20142017. http://www.bps.go.id/. [25 Juli 2017].

[DPR] Biro Analisa Anggaran dan Pelaksanaan APBN - SETJEN DPR-RI. 2016. Permasalahan dan upaya peningkatan produktivitas pertanian. http://www.dpr.go.id/doksekjen. [8 Mei 2017].
Darwis V, Iqbal M. 2010. Keragaan pemanfaatan dan sumber pinjaman usaha tani padi sawah. Pusat sosial ekonomi dan kebijakan pertanian 557572.

Dermoredjo. 2014. Analisis kebijakan pengembangan padi, jagung, dan kedelai di Indonesia dalam menghadapi perdagangan bebas asean. Jurnal Analisis Kebijakan Pertanian 12(1):51-68. https://doi.org/10.21082/akp.v12n1.2014.51-68.

Firdaus M. 2011. Aplikasi Ekonometrika untuk Data Panel dan Time Series. Bogor: IPB Press.

Firdaus M. 2015. Petani padi bisa sejahtera?. http://m. republika.co.id. [24 juli 2017].

Ismail AG, Zaenal MH, Shafiai H. 2013. Philanthropy in islam: a promise to welfare economics system. IRTI Working Paper Series 1435-03.

Jayadi. 2012. The dynamic analysis of inflation rate and farmers' welfare for rural poverty reduction in Indonesia [tesis]. Depok: UI.

Nurul F. 2016. Masihkah Indonesia negara agraris. http://mediaindonesia.com/index.php/news/. [8 November 2016].

Osorio CG, Abriningrum DE, Armas EB, Firdaus M. 2011. Who Is Benefiting from Fertilizer Subsidies in Indonesia?. Policy Research Working Paper No. 5758.

Oxfam International. 2012. Annual income of richest 100 people enough to end global poverty four times over. http://www.oxfam.org. [9 Juli 2107]

Rodiana N, Nuryartono N, Ayyubi SE. 2014. Efektivitas penerapan bayar pascapanen pada pengembalian pembiayaan akad murabahah pertanian padi di baitul maal wa tamwil as salam, kramat, demak. Jurnal Al-Muzara'ah 2(1):16-34.

Sajogyo. 2002. Pertanian dan kemiskinan. Jurnal Ekonomi Rakyat 1(1): 1-15.

Saptana, Iqbal M,Ar-Rozi AM. 2013.Evaluasi kebijakan tujuh gema revitalisasi dalam pembangunan pertanian. Jurnal Analisis Kebijakan Pertanian 11(2): 107-127. https://doi.org/10.21082/akp. v11n2.2013.107-127.

Sriana J. 2011. The effect of budget deficit shock on government spending: an empirical case in Indonesia. International Journal of Business and Development Studies 3(1):41-58.

Tempo. 2012. Agustus, distribusi pupuk bersubsidi diubah. http://m.tempo.co. [24 Juli 2017]. 